\title{
Nutrient Uptake and Grain Yield Enhancement of Soybean by Integrated Application of Farmyard Manure and NPK
}

\author{
Anjali Chandrol Solanki ${ }^{1 *}$, Manoj Kumar Solanki' ${ }^{2}$ Anil Nagwanshi ${ }^{1}$, \\ A.K. Dwivedi ${ }^{1}$ and B.S. Dwivedi ${ }^{1}$ \\ ${ }^{1}$ Department of Soil science and Agriculture Chemistry, Jawaharlal Nehru Agricultural \\ University, Jabalpur-482004, Madhya Pradesh, India \\ ${ }^{2}$ Department of Food Quality \& Safety, Institute for Post-harvest and Food Sciences, The \\ Volcani Center, Agricultural Research Organization, Rishon LeZion-7528809, Israel \\ *Corresponding author
}

A B S T R A C T

\begin{tabular}{|l|}
\hline Ke y w o r d s \\
$\begin{array}{l}\text { Farmyard manure, } \\
\text { Nodulation, Nutrient } \\
\text { uptake, Photosynthetic } \\
\text { pigment, Soil chemistry }\end{array}$ \\
\hline Article Info \\
\hline $\begin{array}{l}\text { Accepted: } \\
\text { 08 August } 2018 \\
\text { Available Online: } \\
\text { 10 September } 2018\end{array}$ \\
\hline
\end{tabular}

\section{Introduction}

Oil-seed crop Soybean (Glycine max [L.] Merr) is getting globally reputation as largest protein source crop for the animal and human health. Due to the biological nitrogen fixation ability (BNF) through symbiosis of rhizobium bacteria, it mainly used for the rotational crop to secure the soil fertility. Soil organic $\mathrm{N}$ and carbon also enhanced by soybean crop residue (Abebe and Deressa, 2017). In India, soybeangrown area is about $10.33 \mathrm{M}$ ha and average productivity $1.20 \mathrm{tha}^{-1}$ and soybean production
This study aimed to investigate the impact of integrated application of inorganic fertilizer (NPK) and farmyard manure (FYM) on soybean grain nutrient uptake and yield. We performed field experiments with treatments including 100\% NPK, 150\% NPK, $100 \%$ $\mathrm{NPK}+\mathrm{FYM}$ and control (without fertilizer), and soil properties and plant parameters assessed. Greater effects on soil electric conductivity (EC), soil organic carbon (SOC), Soil $\mathrm{N}$ were recorded with treatments. However, soil $\mathrm{P}$ showed significant $(P<0.05)$ interaction ith treatments and time. We found that integrated fertilizer application significantly $(P<0.05)$ enhanced the nodulation rate, total chlorophyll, grain yield and grain nutrient Pver control. Overall, integrated use of $100 \%$ NPK + FYM may optimize NPK uptake efficiency and reduce $\mathrm{N}$ fertilizer losses, which is necessarily required for the sustainable soybean production. This study concluded that FYM with $100 \%$ NPK is a best solution for the sustainable soybean production. 
improve root nodulation, while inorganic fertilizers reduced (Singh et al., 2007; Ramesh et al., 2010).

Organic fertilizers not only improve the soil physical and biological properties, also improved the efficacy of chemical fertilizers (Alam et al., 2010). Organic fertilizers like FYM increased the soil health by inducing the physical, chemical and biological conditions of soil (Hati et al., 2007). As earlier, to maximize the crop production for the industrial markets, chemical fertilizer strategy applied. However, a strong fertilizer system must be established to improve ecofriendly cultivation of soybean. Past researchers discussed that integrated use of organic and inorganic fertilizers has a positive effect on soil nutrient availability, it optimizes the soil micro- environment and improves crop productivity (Dong et al., 2012; Abebe and Deressa, 2017). Moreover, proportion of organic and inorganic fertilizers as per the specific soil type is required to develop the soil fertility and crop productivity. Present study focused on the assessment of the organic fertilizer (FYM) and inorganic fertilizers (NPK) application impact on the soybean nodulation, photo-light pigment, and grain yield and nutrients uptake.

\section{Materials and Methods}

Present study performed during 2015 in Kharif season at experimental site of Jawaharlal Nehru Krishi Vishwa Vidyalaya, Jabalpur, Madhya Pradesh, India $\left(23^{\circ} 10^{\prime} \mathrm{N}, 7^{\circ} 57^{\prime} \mathrm{E}\right)$, under wheat (Triticum aestivum L.) as winter and soybean (Glycine max) as summer crops. The region has a semi-arid and sub-tropical climate, with a mean annual temperature of $25.7^{\circ} \mathrm{C}$ and precipitation of $1350 \mathrm{~mm}$. Soil details; medium black soil classified as Vertisol, with $\mathrm{pH}$ of 7.6 in soil-water suspension (1:2.5), $0.18 \mathrm{dS} \mathrm{m}^{-1}$ electrical conductivity, $0.57 \%$ organic carbon, $193.0 \mathrm{~kg}$ ha $^{-1}$ available $\mathrm{N}, 7.60 \mathrm{~kg} \mathrm{ha}^{-1}$ available $\mathrm{P}$, and $370 \mathrm{~kg} \mathrm{ha}{ }^{-1}$ available $\mathrm{K}, 17.47 \mathrm{~kg} \mathrm{ha}^{-1}$ available $S$ and $0.33 \mathrm{~kg} \mathrm{ha}^{-1}$ available $\mathrm{Zn}$, and bulk density of $1.3 \mathrm{Mg} \mathrm{m}^{-3}$, and particle size distribution of $56.82 \%$ clay, $17.91 \%$ silt, and $25.27 \%$ sand. All metrological observations given in Table 1. The gross plot size being $17 \times 10.8 \mathrm{~m}$ with $1 \mathrm{~m}$ spacing in between the plots and $2 \mathrm{~m}$ spacing between the replications. An additional strip was also retained as no crop control (fallow strip) by the side of the main experiment. We used four treatments strategy with Soybean variety JS 97-52; included; $100 \%$ NPK $(43.4,500$, and $33.33 \mathrm{~kg} \mathrm{ha}^{-1} \mathrm{~N}, \mathrm{P}$, and $\mathrm{K}$, respectively), $150 \%$ NPK $\left(65.1,750\right.$, and $49.99 \mathrm{~kg} \mathrm{ha}^{-1} \mathrm{~N}, \mathrm{P}$, and $\mathrm{K}$, respectively), combination of $100 \% \mathrm{NPK}+$ FYM (5 $\left.\mathrm{t} \mathrm{ha}^{-1}\right)$, and no fertilizer (control). Inorganic fertilizers include urea $\left(460 \mathrm{~g} \mathrm{~kg}^{-1}\right.$ of total $\mathrm{N})$, super phosphate $\left(160 \mathrm{~g} \mathrm{~kg}^{-1}\right.$ of total $\mathrm{P}$ ), and potassium chloride $\left(600 \mathrm{~g} \mathrm{~kg}^{-1}\right.$ of total $\mathrm{K}$ ) as the sources of $\mathrm{N}, \mathrm{P}$, and $\mathrm{K}$, respectively.

Soil samples were collected from each treatment before showing and after harvesting, five random cores were taken from a depth of 0 to $20 \mathrm{~cm}$ using a sampling auger. Subsamples were pooled to make composite samples. Composite samples were air-dried at room temperature, pulverized, sieved through a 2-mm sieve, and chemical properties like $\mathrm{pH}$ (1:2.5 water extraction), electrical conductivity (Piper, 1950), organic carbon (Walkley and Black, 1934), available N (Subbiah and Asija, 1956), available P (Olsen, 1954; Millar and Keeney, 1982) and available K (Muhr et al., 1965) were assessed.

For the plant attributes, ten plants were selected from the each plot area, and nodule parameters and total chlorophyll (Arnon, 1949)was measured at different growth stages (25, 45 and 60 days after sowing). All soybean plants were harvested at crop maturity, and grain parameters like number of pods, grain 
yield, test weight, harvesting index were obtained. After harvesting five tagged plants were collected from, each plot and pods were counted manually and grain test weight was obtained through 1000 grains weight. After threshing of all plants, harvesting index were calculated by using this formula: $\mathrm{HI}=$ (Economic yield/ biological yield) $\times 100$ (Snyder and Carlson, 1984). Next to this, grain nutrients NPK were analyzed (Bradstreet, 1965; Bhargava and Raghupati, 1993) and nutrient uptake was calculated by using the following formula: Nutrient uptake $\left(\mathrm{kg}^{-1} \mathrm{ha}\right)=$ Nutrient content $(\%) \times$ yield $\left(\mathrm{kg} \mathrm{ha}^{-1}\right)$.

For the statistical analysis, data were used as mean \pm standard error of four replicates. Significant among treatments was calculated according to Duncan's Multiple Range Test (DMRT). Origin Pro (Origin Lab Corporation, USA) was used for graphs. Box plot indicates the mean by Small Square, the median by central line and Box limits indicate the 25th and 75th percentiles. Whiskers represent the 5th and the 95th percentiles. Black dots showing low and high value of plotted data. Same letter are not significantly different $(P \leq$ 0.05 ) according to DMRT.

\section{Results and Discussion}

\section{Soil properties and nutrients}

FYM addition as well as composting with various organic supplements have been found to be very efficient for soil management (Hati et al., 2007; Alam et al., 2010). Impact of organic and inorganic fertilization on soil $\mathrm{pH}$ have been discussed in past studies (Dong et al., 2012). They confirmed that reduction of $\mathrm{pH}$ with inorganic fertilization. In the present study, we observed that integrated use of NPK and FYM on soil $\mathrm{pH}$ and EC were not significantly influenced much by different treatments. These outcomes are in agreement with Khan et al., (2017), who found that neither residue nor fertilizer treatments had significant influence on soil $\mathrm{pH}$ and EC values. For soil organic carbon (SOC), we observed that there was improvement with integrated use of $\mathrm{NPK}+\mathrm{FYM}$, interestingly $100 \%$ NPK alone showed less SOC as compared to $150 \%$ NPK and $100 \%$ NPK+FYM. However, statistical analysis revealed that fertilization treatments led to a significant increase in SOC compared with the control $(P<0.05)$. Organic carbon of soil enhancement through FYM and plant residues might played important role to increase organic matter (Bandyopadhyay et al., 2010; Abebe and Deressa, 2017). Our results showed similarity with the data published by Bandyopadhyay et al., (2010) and Hati et al., (2007) who discussed about effects of manure and inorganic fertilizer applications on SOC. Moreover, soil NPK results also showed less significant pattern with all three fertilization treatments, but maximum NPK resulted with $100 \%$ NPK+FYM. We sampled surface soil $(0-20 \mathrm{~cm})$ for the NPK and higher organic matter may be inducing the soil nutrients (Table 2). These results also agreement with Khan et al., (2017). Conversely, two-way ANOVA results showed significant $(P=0.02)$ interaction between treatment and time with soil $\mathrm{P}$ only, it showed soil total $\mathrm{P}$ played important role in soil fertility and soil mineralization and integrated management practices had a positive influence on the soil P. It also suggesting that integrated application can enhance the use of $\mathrm{P}$ and it influence the plant nodulation and grain yield (Table 2). These results also supported by Dong et al., 2012, Abebe and Deressa (2017) and Khan et al., (2017). According to our results, SOC and NPK concentration increased considerably in the integrated use of NPK + FYM compared to the control, suggesting that chemical and organic fertilizer are useful to the fortification of soil organic matter, thereby improving soil fertility. 
Table.1 Meteorological data during the field experiment (2015)

\begin{tabular}{|c|c|c|c|c|c|c|c|c|}
\hline \multirow{2}{*}{$\begin{array}{l}\text { Meteorological } \\
\text { weeks }\end{array}$} & \multicolumn{2}{|c|}{ Temperature $\left({ }^{0} \mathrm{C}\right)$} & \multicolumn{2}{|c|}{ Relative humidity (\%) } & \multirow{2}{*}{$\begin{array}{l}\text { Wind } \\
\text { velocity (hrs }_{\left.\text {day }^{-1}\right)}\end{array}$} & \multirow{2}{*}{$\begin{array}{l}\text { Sun Shine } \\
\left(\text { hrs day }^{-1}\right)\end{array}$} & \multirow{2}{*}{$\begin{array}{l}\text { Rainfall } \\
(\mathrm{mm})\end{array}$} & \multirow{2}{*}{$\begin{array}{l}\text { Rainy } \\
\text { days }\end{array}$} \\
\hline & Max. & Min. & Max. & Min. & & & & \\
\hline 27 & 34.5 & 24.4 & 85 & 62 & 6.9 & 5.6 & 296.8 & 3 \\
\hline 28 & 31.3 & 23.9 & 88 & 77 & 6.3 & 4.7 & 116.0 & 4 \\
\hline 29 & 32.3 & 24.1 & 90 & 76 & 6.6 & 3.1 & 117.5 & 3 \\
\hline 30 & 28.2 & 22.8 & 95 & 88 & 6.9 & 3.0 & 119.9 & 5 \\
\hline 31 & 26.3 & 22.0 & 94 & 87 & 7.6 & 0.0 & 32.4 & 4 \\
\hline 32 & 27.7 & 22.7 & 96 & 88 & 6.0 & 1.2 & 145.8 & 5 \\
\hline 33 & 28.2 & 23.0 & 89 & 81 & 5.9 & 0.8 & 101.8 & 5 \\
\hline 34 & 30.2 & 22.9 & 92 & 77 & 6.3 & 4.9 & 84.4 & 4 \\
\hline 35 & 31.9 & 24.2 & 92 & 69 & 3.0 & 4.8 & 3.0 & 0 \\
\hline 36 & 30.8 & 23.9 & 93 & 79 & 5.4 & 2.8 & 52.2 & 3 \\
\hline 37 & 30.7 & 23.4 & 91 & 79 & 5.1 & 2.8 & 87.4 & 2 \\
\hline 38 & 30.8 & 23.1 & 89 & 69 & 3.9 & 4.6 & 11.0 & 1 \\
\hline 39 & 31.9 & 22.6 & 88 & 51 & 3.1 & 8.7 & 0.0 & 0 \\
\hline 40 & 33.4 & 21.9 & 91 & 44 & 3.3 & 7.3 & 2.3 & 0 \\
\hline 41 & 32.4 & 18.5 & 83 & 35 & 2.9 & 9.0 & 0.0 & 0 \\
\hline 42 & 32.5 & 18.6 & 79 & 32 & 2.4 & 9.4 & 0.0 & 0 \\
\hline 43 & 31.6 & 15.2 & 82 & 35 & 1.9 & 8.4 & 0.0 & 0 \\
\hline
\end{tabular}


Table.2 Effect of integrated application of fertilizer and FYM on soil physico-chemical properties

\begin{tabular}{|c|c|c|c|c|c|c|c|}
\hline Treatments & Sampling time & pH & $\mathrm{EC}\left(\mathrm{dSm}^{-1}\right)$ & $\mathrm{SOC}\left(\mathrm{g} \mathrm{kg}^{-1}\right)$ & Available $\mathbf{N}^{\#}$ & Available $\mathbf{P}^{\#}$ & Available $\mathbf{K}^{\#}$ \\
\hline \multirow[t]{2}{*}{$100 \%$ NPK } & Showing & $7.57 \pm 0.00^{\mathrm{a}}$ & $0.18 \pm 0.01^{\mathrm{ab}}$ & $7.48 \pm 0.17^{\mathrm{b}}$ & $262.50 \pm 14.93^{b}$ & $32.99 \pm 1.69^{c}$ & $280.00 \pm 9.13^{c}$ \\
\hline & Harvesting & $7.60 \pm 0.04^{\mathrm{a}}$ & $0.19 \pm 0.01^{\mathrm{ab}}$ & $7.57 \pm 0.14^{b}$ & $266.25 \pm 11.61^{b}$ & $35.32 \pm 2.07 b^{c}$ & $285.93 \pm 10.60^{\mathrm{bc}}$ \\
\hline \multirow[t]{2}{*}{$150 \%$ NPK } & Showing & $7.61 \pm 0.06^{\mathrm{a}}$ & $0.19 \pm 0.01^{\mathrm{ab}}$ & $8.36 \pm 0.36^{\mathrm{a}}$ & $307.50 \pm 16.52^{\mathrm{ab}}$ & $38.63 \pm 1.88^{\mathrm{ab}}$ & $315.00 \pm 13.23^{\mathrm{abc}}$ \\
\hline & Harvesting & $7.62 \pm 0.10^{\mathrm{a}}$ & $0.20 \pm 0.00^{\mathrm{a}}$ & $8.61 \pm 0.38^{\mathrm{a}}$ & $322.50 \pm 16.52^{\mathrm{a}}$ & $39.63 \pm 1.53^{\mathrm{ab}}$ & $320.00 \pm 14.72^{\mathrm{ab}}$ \\
\hline \multirow[t]{2}{*}{$100 \% \mathrm{NPK}+\mathrm{FYM}$} & Showing & $7.55 \pm 0.06^{\mathrm{a}}$ & $0.17 \pm 0.01^{\mathrm{ab}}$ & $8.82 \pm 0.25^{\mathrm{a}}$ & $322.50 \pm 19.31^{\mathrm{a}}$ & $40.51 \pm 1.09^{\mathrm{a}}$ & $327.50 \pm 20.16^{\mathrm{a}}$ \\
\hline & Harvesting & $7.54 \pm 0.09^{a}$ & $0.18 \pm 0.01_{\mathrm{ab}}$ & $8.90 \pm 0.15^{\mathrm{a}}$ & $326.75 \pm 22.56^{\mathrm{a}}$ & $41.88 \pm 1.76^{\mathrm{a}}$ & $330.00 \pm 15.81^{\mathrm{a}}$ \\
\hline \multirow[t]{2}{*}{ Control } & Showing & $7.51 \pm 0.08^{\mathrm{a}}$ & $0.15 \pm 0.02^{b}$ & $4.22 \pm 0.30^{c}$ & $185.00 \pm 17.08^{c}$ & $9.73 \pm 0.72^{\mathrm{d}}$ & $215.00 \pm 6.45^{\mathrm{d}}$ \\
\hline & Harvesting & $7.49 \pm 0.08^{\mathrm{a}}$ & $0.16 \pm 0.02^{\mathrm{ab}}$ & $4.21 \pm 0.30^{c}$ & $183.75 \pm 15.46^{\mathrm{c}}$ & $8.81 \pm 1.09^{\mathrm{d}}$ & $212.50 \pm 8.54^{d}$ \\
\hline SEM & & 0.07 & 0.01 & 0.23 & 17.34 & 1.50 & 12.39 \\
\hline CV\% & & 1.9 & 15.3 & 6.2 & 12.7 & 9.7 & 8.7 \\
\hline \multicolumn{8}{|l|}{$P$ values ${ }^{@}$} \\
\hline Treatments & & 0.41 & $0.03^{*}$ & $0.00^{* *}$ & $0.00^{* *}$ & 0.07 & 0.79 \\
\hline Time & & 0.97 & 0.21 & 0.60 & 0.66 & 0.81 & 0.89 \\
\hline Treatments $\times$ Time & & 0.99 & 1.00 & 0.97 & 0.97 & $0.02^{*}$ & 0.99 \\
\hline
\end{tabular}

Table.3 Effect of integrated application of fertilizer and FYM on soybean yield parameters

\begin{tabular}{|c|c|c|c|c|}
\hline Treatments & Total Pods & Test weight (g) & Grain yield $\left(\mathrm{kg} \mathrm{ha}^{-1}\right)$ & HI (\%) \\
\hline $100 \%$ NPK & $58.50 \pm 2.22^{b}$ & $55.45 \pm 1.49^{\mathrm{a}}$ & $900.00 \pm 20.41^{\mathrm{b}}$ & $31.30 \pm 0.51^{\mathrm{a}}$ \\
\hline $150 \% \mathrm{NPK}$ & $65.25 \pm 2.14^{\mathrm{ab}}$ & $56.78 \pm 2.35^{\mathrm{a}}$ & $1150.00 \pm 20.41^{\mathrm{a}}$ & $36.44 \pm 1.85^{\mathrm{a}}$ \\
\hline $100 \% \mathrm{NPK}+\mathrm{FYM}$ & $67.50 \pm 2.78^{\mathrm{a}}$ & $57.37 \pm 2.96^{\mathrm{a}}$ & $1200.00 \pm 20.41^{\mathrm{a}}$ & $37.33 \pm 1.98^{\mathrm{a}}$ \\
\hline SEM & 2.36 & 1.77 & 46.82 & 1.91 \\
\hline CV (\%) & 8 & 6.5 & 10.5 & 12.8 \\
\hline
\end{tabular}



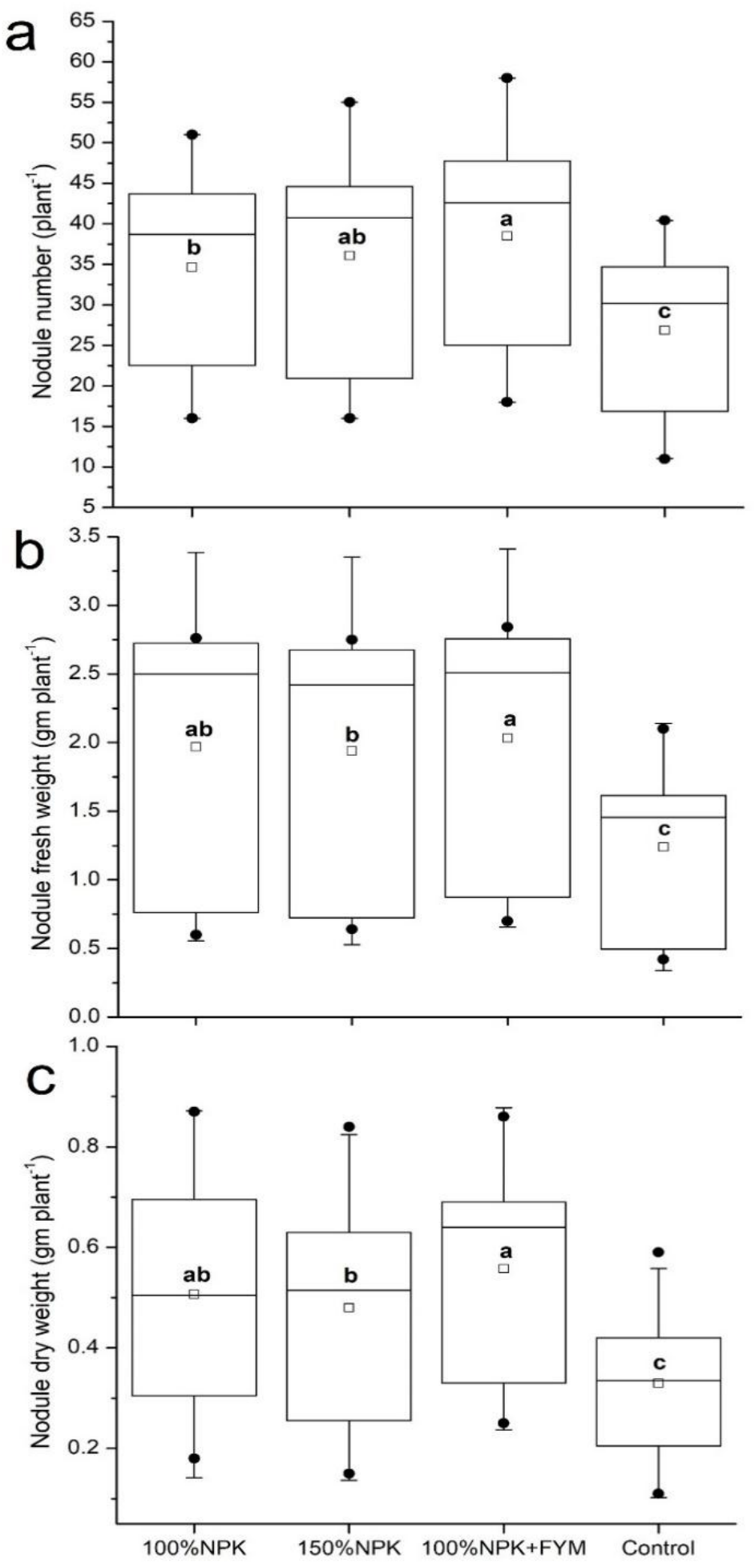

Figure.1 Effect of integrated application of NPK and FYM on nodule parameters of soybean plants; (a) number of nodule, (b) nodule fresh weight, and (c) nodule dry weight. Box graphs represents mean $(n=12)$ of three sampling times $(25,45$ and 60 days after sowing) 
Int.J.Curr.Microbiol.App.Sci (2018) 7(9): 1093-1102

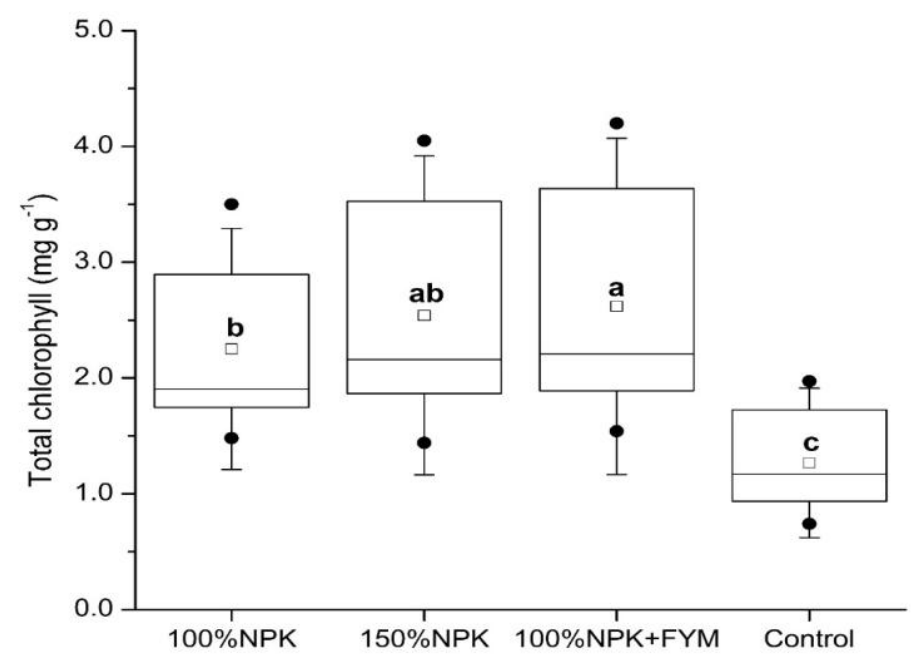

Figure.2 Effect of integrated application of NPK and FYM on total chlorophyll content of soybean plant. Box graphs represents the pooled values mean $(n=12)$ of three sampling times $(25,45$ and 60 days after sowing)

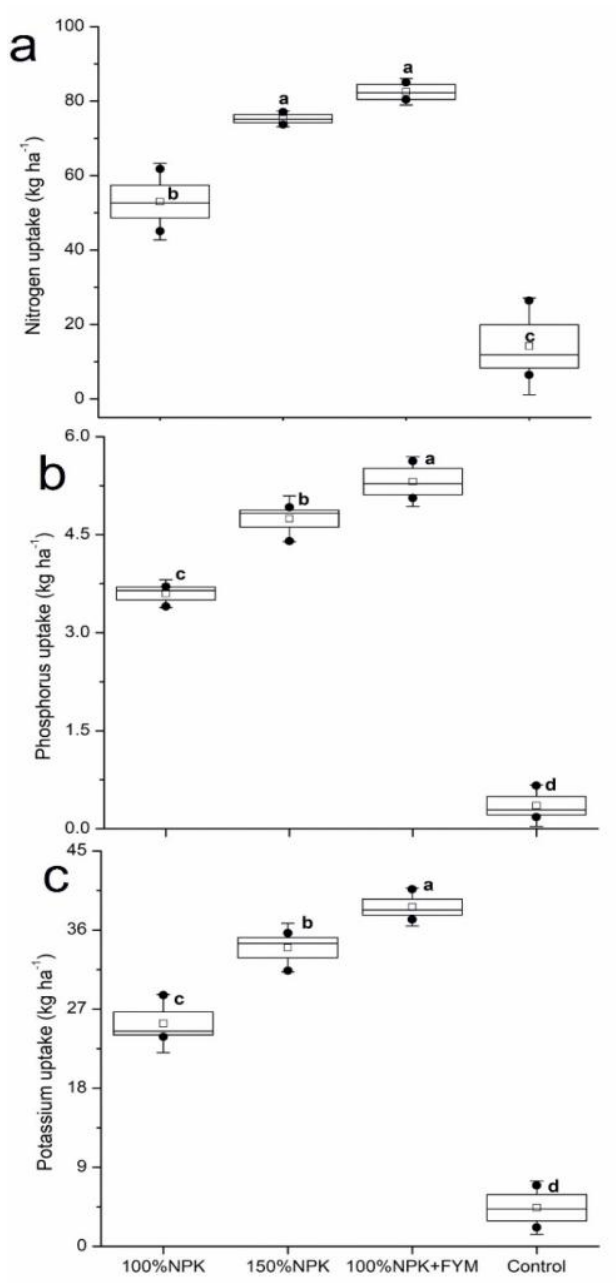

Figure.3 Effect of integrated application of fertilizer and FYM on soybean grain nutrient uptake;

(a) N uptake, (b) P uptake and (c) K uptake. Box graphs plotted by mean $(n=4)$ after harvesting of grains 


\section{Nodule formation and chlorophyll content}

Effect of organic fertilizer on nodulation have been reported previously (Bekere et al., 2013; McCoy et al., 2018). In the present study, we found that nodule number, nodule weight (fresh and dry) per plant of the crop were significantly influenced by integrated use of NPK+FYM (Figure 1), it significantly $(P<$ 0.05 ) improved nodule number (Fig. 1a), nodule fresh weight (Fig. 1b) and nodule dry weight (Fig. 1c) per plant over 100\% NPK and control. Higher amount of inorganic fertilizer inhibits the nitrogen fixation but lower amount stimulate increase $\mathrm{N}_{2}$ fixation in early stage of plant (Bekere et al., 2013). Integrated use of NPK+FYM neutralize the toxic effect of inorganic compounds and increase the soil organic matter, and it maintained soil health and biodiversity for the longer time (Dong et al., 2012; Bekere et al., 2013).

The soybean yield usually depends on the $\mathrm{N}$ accumulation and chlorophyll content in leaves. $\mathrm{N}$ supply increases the leaf area of plants and accordingly that influences the photosynthesis activity. Our results indicated that different treatments showed different leaf chlorophyll contents in soybean (Fig. 2). The total leaf chlorophyll concentration significantly increased with NPK+FYM and $150 \%$ NPK, as compared with $100 \%$ NPK and control. Integrated fertilizer application resulted in greater amount of chlorophyll content. While lowest content was noted with $100 \% \mathrm{~N}$ alone and control. Similar finding has also been reported by Alam et al., (2010), that lower chlorophyll content would limit the photosynthetic potential, lead to a decrease in biomass, and yield.

\section{Yield parameters and nutrient uptake}

Te present study observed that maximum soybean pods, test weight and yield recovered from $100 \% \mathrm{NPK}+\mathrm{FYM}$, and it significant different with $100 \%$ NPK and control. There was similar trend found with $100 \%$ $\mathrm{NPK}+\mathrm{FYM}$ and $150 \% \mathrm{NPK}$ and a decline noticed in $100 \%$ NPK with soybean parameters. The test biomass of soybean grain was higher $(\mathrm{P}<0.05)$ in FYM treated plants and treatment showed significant difference only with control. Similar finding has also been reported by Bandyopadhyay et al., (2010), Hati et al., (2007), Singh et al., (2007). The higher average soybean yield obtained with $100 \%$ NPK+FYM $(1200.00$ $\left.\pm 20.41 \mathrm{~kg} \mathrm{ha}^{-1}\right)$, with $150 \%$ NPK (1150.00 $\left.\pm 20.41 \mathrm{~kg} \mathrm{ha}^{-1}\right)$, with $100 \%$ NPK $(900.00$ $\left.\pm 20.41 \mathrm{~kg} \mathrm{ha}^{-1}\right)$ and control $(312.50 \pm 85.09 \mathrm{~kg}$ $\mathrm{ha}^{-1}$ ) (Table 3). The data clearly correlated that addition of integrated application of fertilizer with FYM was found to be beneficial for maintaining the soil fertility as well as crop productivity (Hati et al., 2007; Bhattacharyya et al., 2008).

For nutrient uptake results indicated that maximum N uptake resulted with 100\% NPK+FYM treatment and followed by $150 \%$ NPK and 100\% NPK over the control (Fig. $3 a)$. These results agreed with Hati et al., (2007) and Bandyopadhyay et al., (2010) reports. Moreover, similar trends also fallowed by $\mathrm{P}$ uptake with the $100 \%$ NPK + FYM treatment. It was significant $(P<$ 0.05 ) different as compared with $100 \%$ NPK and control (Fig. 3b). Similar kind of finding have been also reported by Sharma and Vikas (2007). The $\mathrm{K}$ uptake in soybean grain also showed progressive increase $(P<0.05)$ with NPK+FYM over control. Our results corroborate the previous studies which reported that organic amendments like FYM enhanced the nutrient uptake of soybean grain (Singh et al., 2007; Bandyopadhyay et al., 2010; Ramesh et al., 2010).

Integrated fertilization (NPK+FYM) significantly enriched the soil fertility, which 
improved the rate of nodulation and photosynthesis. It caused a positively influence on the grain yield and grain nutrient uptake. On average, soybean yields were 3.8 times higher in the integrated fertilized treatments than unfertilized control. FYM application rapidly increased soil $\mathrm{N}$ and $\mathrm{P}$, thereafter plant nodulation enhanced and that fixed nitrogen helps to the plant for metabolic activities such as chlorophyll. Higher chlorophyll is a plant health indicator and it increases the pods number and grain test weight. Similar trends also followed by the higher application of NPK (150\%). However, application rates $150 \%$ NPK were too high, and FYM could have partially replaced the NPK fertilizer inputs. The effectiveness of these measures needs to be tested further in the field with NPK-FYM-Microbes-nutrient strategies.

\section{Acknowledgement}

This work was supported by all India Coordinated Research Project on Long-Term Fertilizer Experiments project of Indian Council of Agricultural Research (ICAR), New Delhi.

\section{References}

Abebe Z, and Deressa H (2017) The effect of organic and inorganic fertilizers on the yield of two contrasting soybean varieties and residual nutrient effects on a subsequent Finger Millet Crop. Agronomy 7:42.

Alam M, Siddiqua A, Chowdhury M, and Prodhan M (2010) Nodulation, yield and quality of soybean as influenced by integrated nutrient management. $J$ Bangladesh Agric Univ 7:229-234.

Arnon DI (1949) Copper enzymes in isolated chloroplasts. polyphenoloxidase in Beta vulgaris. Plant Physiol 24:1-15.

Bandyopadhyay KK, Misra AK, Ghosh PK, and Hati KM (2010) Effect of integrated use of farmyard manure and chemical fertilizers on soil physical properties and productivity of soybean. Soil Tillage Res 110:115-125.

Bekere W, Kebede T, and Dawud J (2013) Growth and nodulation response of soybean (Glycine $\max$ L.) to lime, Bradyrhizobium japonicum and nitrogen fertilizer in acid soil at Melko, south western Ethiopia. Int J Soil Sci 8:25-31.

Bhargava BS, and Raghupati HB (1993) Analysis of plant materials for macro and micronutrients, in Methods of Analysis of Soil, Plants, Water and Fertilizers (Tandon HLS ed) pp 49-82, FDCO, New Delhi.

Bhattacharyya R, Kundu S, Prakash V, and Gupta HS (2008) Sustainability under combined application of mineral and organic fertilizers in a rainfed soybeanwheat system of the Indian Himalayas. Eur J Agron 28:33-46.

Bradstreet RB (1965) The Kjeldahl Method for Organic Nitrogen, Academic Press, London.

Dong W, Zhang X, Wang H, Dai X, Sun X, Qiu W, and Yang F (2012) Effect of different fertilizer application on the soil fertility of paddy soils in red soil region of southern China. PLoS One 7:e44504.

Hati KM, Swarup A, Dwivedi AK, Misra AK, and Bandyopadhyay KK (2007) Changes in soil physical properties and organic carbon status at the topsoil horizon of a vertisol of central India after 28 years of continuous cropping, fertilization and manuring. Agric Ecosyst Environ 119:127-134.

Khan AM, Kirmani NA, and Wani FS (2017) Effect of INM on soil carbon pools, soil quality and Sustainability in RiceBrown Sarson cropping system of Kashmir valley. Int.J.Curr. 
Microbiol.App.Sci. 6:785-809.

McCoy JM, Kaur G, Golden BR, Orlowski JM, Cook DR, Bond JA, and Cox MS (2018) Nitrogen Fertilization of Soybean Affects Root Growth and Nodulation on Two Soil Types in Mississippi. Commun Soil Sci Plant Anal 49:181-187.

Millar R, and Keeney D (1982) Method of soil Analysis. Part-II, American Society Agronomy, Madison Wiscosin, USA.

Muhr G, Data N, Subramany H, VK L, and Dunahue R (1965) Soil testing, India Asian Press, New Delhi.

Olsen SR (1954) Estimation of available phosphorus in soils by extraction with sodium bicarbonate, U.S. Dept. of Agriculture, Washington.

Piper C (1950) Soil and Plant Analysis, Intel Science Publishers, Inc. New York.

Ramesh P, Panwar NR, and Singh AB (2010) Crop productivity, soil fertility and economics of soybean (Glycine max), chickpea (Cicer arietinum) and blond psyllium (Plantago ovata) under organic nutrient management practices. Indian $J$
Agric Sci 80:965-969.

Sharma V, and Vikas A (2007) Effect of phosphorous and zinc application on yield and uptake of $\mathrm{P}$ and $\mathrm{Zn}$ by chickpea under rainfed conditions. $J$ food Legum 20:49-51.

Singh SR, Najar GR, and Singh U (2007) Productivity and nutrient uptake of soybean (Glycine max) as influenced by bio-inoculants and farmyard manure under rainfed conditions. Indian $J$ Agron 52:325-329.

Snyder FW, and Carlson GE (1984) Selecting for partitioning of photosynthetic products in crops. Adv Agron 37:47-72.

SOPA (2016) The Soybean Processors Association of India.

Subbiah B, and Asija E (1956) A rapid procedure for estimation of available nitrogen in soil. Curr Sci 25:259-260.

Walkley A, and Black IA (1934) An examination of the Degtjareff method for determining soil organic matter, and a proposed modification of the Chromic acid titration method. Soil Sci 37:29-38.

\section{How to cite this article:}

Anjali Chandrol Solanki, Manoj Kumar Solanki, Anil Nagwanshi, A.K. Dwivedi and Dwivedi, B.S. 2018. Nutrient Uptake and Grain Yield Enhancement of Soybean by Integrated Application of Farmyard Manure and NPK. Int.J.Curr.Microbiol.App.Sci. 7(09): 1093-1102. doi: https://doi.org/10.20546/ijcmas.2018.709.130 